\title{
Two-photon Absorption Engineering of 5-(Fluorenyl)-1,10-phenanthroline-based Ru(II) Complexes
}

\author{
Olivier Mongin ${ }^{a}$, Mickael Four ${ }^{b}$, Sylviane Chevreux ${ }^{b}$, Mireille Blanchard-Descec ${ }^{c}$ \\ and Gilles Lemercier ${ }^{\star b}$
}

\begin{abstract}
This study deals with the fine tuning of the photophysical characteristics, and especially two-photon absorption (2PA) properties, of several homo- and heteroleptic ruthenium(I) complexes involving 5-substituted1,10-phenanthroline ligands. The 2PA spectra of the complexes were determined in the 700-930 nm range by investigating their two-photon excited luminescence (2PEL). Structure - linear and nonlinear optical properties correlations are discussed, and potential applications (therapy and optical power limiting in the near infrared) can be anticipated.
\end{abstract}

Keywords: 5-(Fluorenyl)-1,10-phenanthroline ligands · Luminescence properties · Ruthenium(II) complexes Two-photon absorption

The two-photon absorption process (2PA) has received considerable attention due to its large number of potential applications ${ }^{[1]}$ such as photodynamic therapy, ${ }^{[2]}$ photochemical delivery of biological messengers, ${ }^{[3]}$ confocal microscopy, ${ }^{[4]}$ threedimensional data storage, ${ }^{[5]}$ micro-fabrication ${ }^{[6]}$ and optical power limiting. ${ }^{[7]}$ Despite the undisputable advantages of coordination complexes ${ }^{[8]}$ over organic chromophores, ${ }^{[9]}$ they remain less studied for 2PA applications. In fact, they offer synthetic tailorability ${ }^{[10]}$ and the access to a MLCT (metal-to-ligand charge transfer) triplet excited state. This triplet MLCT ( ${ }^{3}$ MLCT) state presents a long luminescence lifetime (a few microseconds for Ru(II) complexes for example[11]) which can enable several photophysical processes, used for multiple applications: (i) two-photon excited fluorescence (2PEF) emission, for biological imaging, ${ }^{[12]}$ (ii) energy transfer to a quencher, for $\mathrm{O}_{2}$ sensing, , ${ }^{12]}$ or (iii) excited state re-absorption, for optical power limiting. ${ }^{[13]}$ For this study, we focused on the design of new Ru(II) complexes, siege of MLCT electronic transitions by 2PA.

\footnotetext{
"Correspondence: Prof. G. Lemercier ${ }^{b}$

E-mail: gillles.lemercier@univ-reims.fr

aUniversité Rennes 1, UMR CNRS 6226

Institut des Sciences Chimiques de Rennes

Campus de Beaulieu

35042 Rennes cedex, France

bUniversité Reims Champagne-Ardenne

ICMR UMR CNRS n`7312

Groupe Chimie de Coordination

BP 1039 - 51687 Reims Cedex 2, France

cUniversité Bordeaux

ISM, Centre National de la Recherche Scientifique

UMR 5255, F-33400 Talence, France
}

In spite of their high stability and inertia in solution, which allow their utilization in practical applications, few studies (and only at a single wavelength: 750,800 , and $880 \mathrm{~nm}$ ) were performed for $\mathrm{Ru}(\mathrm{II})^{[14]}$ and $\operatorname{Re}(\mathrm{I})^{[15]}$ complexes on MLCT transitions by $2 \mathrm{PA}$, or Z-scan experiments giving rise to two-photon transitions spectra.[16]

Octupolar coordination Ru(II)-polypyridyl complexes have already been investigated for their stability, inertness, biological activity such as DNA interaction, ${ }^{[17]}$ and optical properties such as ${ }^{3}$ MLCT excited-state properties, ${ }^{[11 a, 18]}$ second-order nonlinear optical properties, ${ }^{[10 c, 19]}$ and two-photon absorption (2PA) ${ }^{[20]}$ leading to a wide range of applications in therapy, ${ }^{[21]}$ dye-sensitized solar cells (DSCs), ${ }^{[22]}$ and organic light-emitting diodes (OLEDs). One can exploit (i) the excited-state absorption for optical power limiting (OPL) ${ }^{[23]}$ applications, but also (ii) the triplet character of the excited-state of Ru(II) complexes for use as oxygen sensors ${ }^{[24]}$ or sensitizers. ${ }^{[25]}$

As a potential application for these systems (supramolecular edifices siege of efficient two-photon absorption), the OPL goal is to protect detectors as well as the eyes from high-power pulsed lasers. 2PA gives access to an excited state and a third photon is absorbed from this excited state $([2+1]$ photons process). Singlet states of organic molecules can enable excited-state absorption (ESA). However, metallic complexes such as $\mathrm{Ru}(\mathrm{II})$ compounds, ${ }^{[26]}$ displaying excited states with longer lifetimes, can favour this phenomenon. The reported fluorene-substituted 1,10-phenanthroline $\mathrm{Ru}$ (II) complexes are good candidates for two-photon based OPL in the near-IR range. 2PA properties of these compounds are strongly linked to the $\pi$-conjugation of the ligands, which can be adjusted by varying the number of fluorene moieties (one or two), and triple bonds (none, one or two $)^{[27]}$ as two-photon absorbers.

\section{Molecular Engineering}

Upon light excitation of Ru(II) complexes, singlet excited states of the ligand or the ${ }^{1}$ MLCT state are reached. From these states, energy is partially transferred to the ${ }^{3}$ MLCT state, responsible for luminescence (in case of linear absorption) or 2PEF (in case of 2PA) of Ru(II) complexes. Therefore, to modulate and optimize 2PA properties of $\mathrm{Ru}(\mathrm{II})$ complexes, molecular engineering of its ligands is relevant. In this paper, the 2PA properties of several homoand heteroleptic ruthenium complexes involving 5-substituted-1,10-phenanthroline ligands (see Fig. 1 for the molecular structures) were studied.

Oligofluorenes are known to display 2PA properties due to excitonic coupling between neighbour monomers, ${ }^{[28]}$ explaining our choice of ligands 1,10-phenantholine (Phen) bearing one or two fluorene units (PF and PFF, respectively). A more conjugated character can be introduced with triple bond between the bipyridyl ligand and the first fluorene (PTF, and PTFF), and between two fluorene units (PTFTF). Homoleptic (Ru3L) and heteroleptic (Ru1L) Ru(II) complexes can be obtained and characterized. Fluorene units were functionalized using triethyleneglycol (Oteg) or hexyl chains in order to modulate their hydrosolubility. 


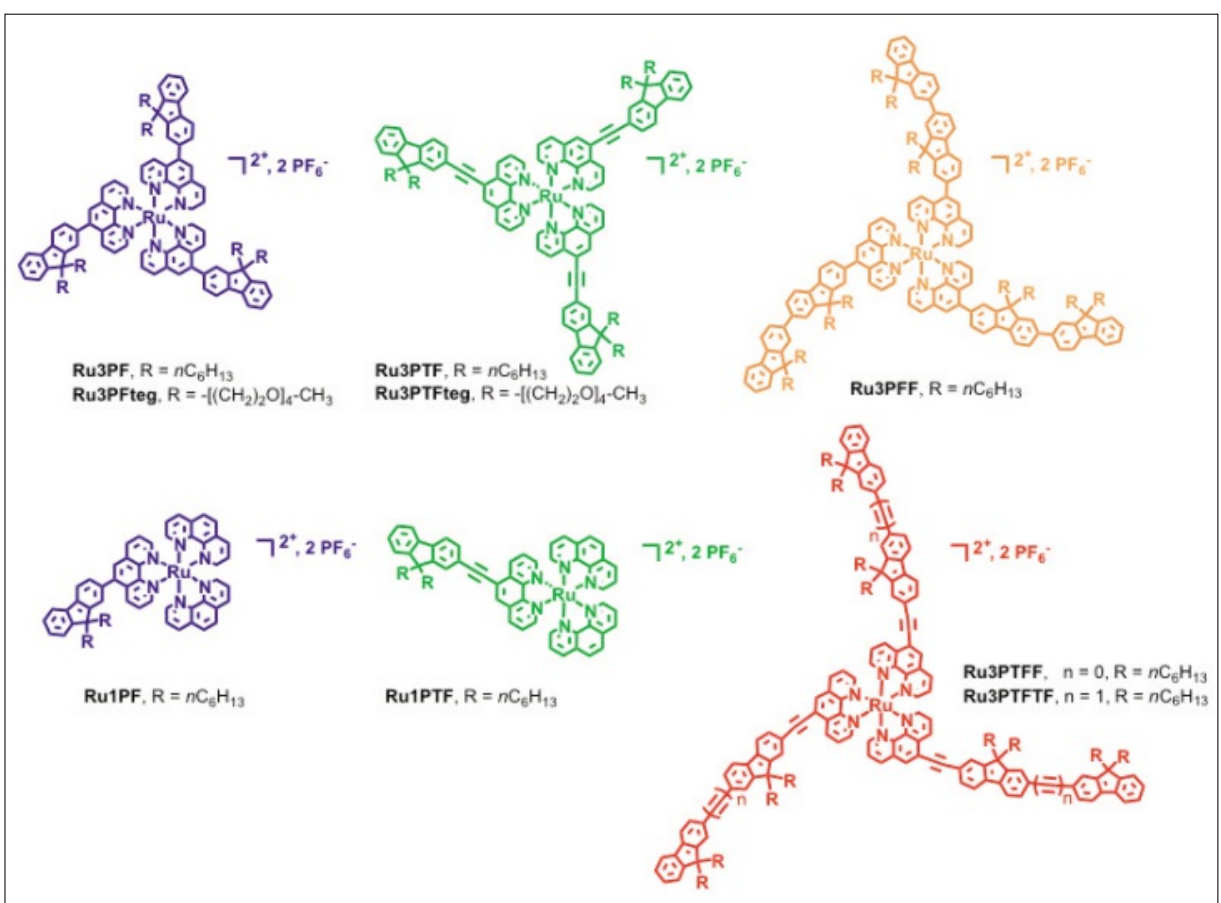

Fig. 1. Molecular structures of homo- and heteroleptic $\mathrm{Ru}(I)$ complexes.

\section{Results and Discussion}

The absorption spectra of the studied complexes are composed of (i) an intense band ranging from 250 to $280 \mathrm{~nm}$ (see Fig. 2), which is due to intra-ligand (IL) transitions $\left(\pi_{\mathrm{L}} \rightarrow \pi_{\mathrm{L}}{ }^{*}\right)$; these transitions are mainly located on the phenanthroline moiety and the intensities are quite similar for all the studied complexes - from $\mathrm{Ru}(\mathrm{Phen})_{3}{ }^{2+}$ to Ru3PTFTF - (ii) a broad band from 380 to $500 \mathrm{~nm}$ which corresponds to $\mathrm{d}\left(\mathrm{Ru}^{\mathrm{II}}\right) \rightarrow \pi^{*}$-metal-to-ligand charge-transfer $\left({ }^{1} \mathrm{MLCT}\right)$ transitions and which is characteristic of this kind of $\mathrm{Ru}(\mathrm{II})$ complex involving polypyridyl-type ligands ${ }^{[20]}$ and finally, (iii) broad bands are recorded from 300 to $400 \mathrm{~nm}$ which are attributed to intra-ligand charge-transfer (ILCT) transitions involving mainly a charge flow from the fluorene unit(s) to the 1,10-phenanthroline moiety; CT are more efficient and appear at lower energy (red shifted) in the presence of a triple bond (Ru3PTF, Ru3PTFF, and Ru3PTFTF). In all cases, the large width of this absorption band should be attributed to vibronic broadenings and/or the overlap of more bands corresponding to different closelying electronic transitions.

The large absorption band ( $\varepsilon$ values around $140000 \mathrm{Lmol}^{-1} \mathrm{~cm}^{-1}$ ), which can be mainly seen for complexes Ru3PFF and Ru3PTFF around $340 \mathrm{~nm}$, can be attributed to a transition due to the existence of an excitonic coupling between the two fluorene units. The electronic transitions at lower energy involve a triple bond-based motif.

The general emission characteristics of the complexes are presented in Table 1. No radiative decay constants. important change can be observed considering the related energies, except a small bathochromic shift (i) for heteroleptic complexes as compared to related homoleptic ones (for example, $\lambda_{\text {em }}$ are 590 and $601 \mathrm{~nm}$ for Ru3PF and Ru1PF, respec-

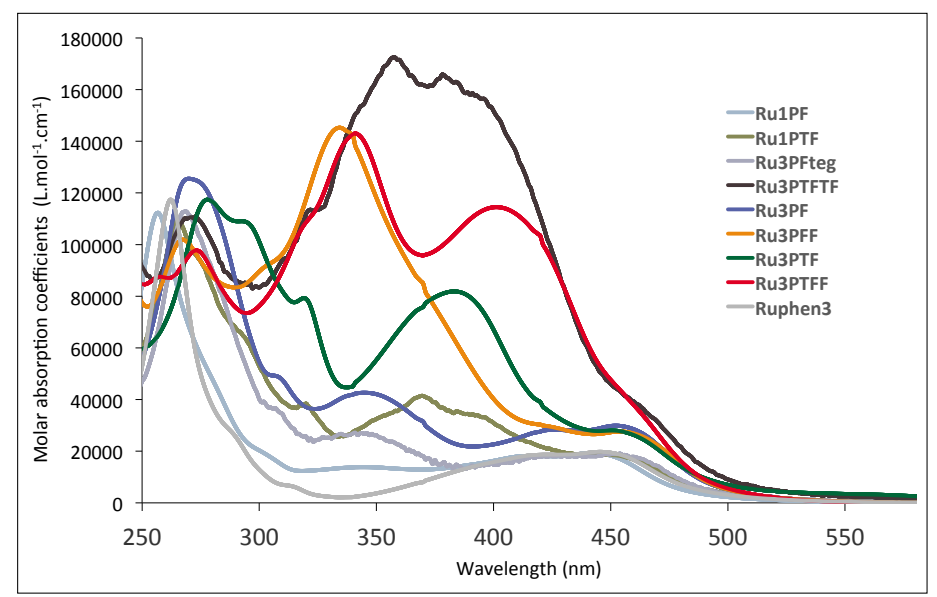

Fig. 2. Absorption spectra of the studied $\mathrm{Ru}(I I)$ complexes.

Table 1. Luminescence properties data of the studied $R u(I I)$ complexes

\begin{tabular}{|l|c|c|c|c|c|c|}
\hline Compound & $\lambda_{\text {em }}[\mathrm{nm}]$ & $\phi$ & $\tau[\mathrm{ns}]$ & $\mathrm{k}_{\mathrm{r}}\left[10^{4} \mathrm{~s}^{-1}\right]$ & $\mathrm{k}_{\mathrm{nr}}\left[10^{4} \mathrm{~s}^{-1}\right]$ & $\mathrm{k}_{\mathrm{r}} / \mathrm{k}_{\mathrm{nr}}$ \\
\hline Ru3PF & 590 & 0.09 & 1700 & 5.3 & 53.5 & 0.10 \\
\hline Ru3PFF & 593 & 0.03 & 2500 & 1.2 & 38.8 & 0.03 \\
\hline Ru3PTF & 599 & 0.11 & 395 & 27.8 & 225.0 & 0.12 \\
\hline Ru3PTFF & 596 & 0.02 & 708 & 2.8 & 137.2 & 0.02 \\
\hline Ru3PTFTF & 601 & 0.05 & 2700 & 1.8 & 34.2 & 0.05 \\
\hline Ru1PF & 601 & 0.05 & 470 & 10.6 & 200.0 & 0.05 \\
\hline Ru1PTF & 613 & 0.04 & 860 & 4.7 & 110.0 & 0.04 \\
\hline Ru(Phen) ${ }_{3}{ }^{2+}$ & 594 & 0.03 & 890 & 3.4 & 110.0 & 0.03
\end{tabular}

Emission wavelength $\lambda_{\mathrm{em}}$ given in acetonitrile; luminescence quantum yield $(\phi)$, and excited state lifetime $(\tau)$ in $\mathrm{CH}_{2} \mathrm{Cl}_{2} ; \phi$ using $\mathrm{Ru}(\mathrm{bipy})^{2+}\left(\phi^{\text {ref }}=0.062\right)$ as ref. [11a]; $\mathrm{k}_{\mathrm{r}}$ and $\mathrm{k}_{\mathrm{nr}}$ : radiative and non- 
corded in the 700-1000 $\mathrm{nm}$ spectral range; this means, in the intra-ligand (IL) chargetransfer band for the higher energy, and in the singlet metal-to-ligand charge-transfer band ( ${ }^{1}$ MLCT) at the higher wavelengths (see Fig. 3). It can be noticed in these spectra that the two-photon absorption cross-section $\left(\sigma\right.$ in GM, and $1 \mathrm{GM}=10^{-50}$ $\mathrm{cm}^{4} \cdot \mathrm{s} \cdot$ molecule $^{-1} \cdot$ photon $\left.^{-1}\right)$ is enhanced when the 1,10-phenanthroline ligand is functionalized, confirming the interest of ligand design in order to modulate charge transfer processes. As expected, being not involved in charge transfer processes, the use of Oteg or hexyl chains as pendent arms of the fluorene units does not induce any $\sigma_{2}$ modification. When the number of fluorene units increases (from Ru3PF to Ru3PFF), $\sigma_{2}$ increases (see Fig. 3, and Table 2). This was already observed and explained, due to the lack of conjugation, by the existence of an excitonic coupling between the fluorene units (also evidenced in the linear absorption spectra). The introduction of a triple bond (from Ru3PF to Ru3PTF, Ru3PFF to Ru3PTFF, Ru3PTFF to Ru3PTFTF, and from Ru3PFteg to Ru3PTFteg) leads to a bathochromic shift, due to the more conjugated character of the ligand. When the number of functionalized 1,10-phenanthroline molecules is reduced from 3 to 1 (from Ru3PF to Ru1PF and from Ru3PTF to Ru1PTF), two-photon absorption cross-section decreases but less than three times, because actually absorption is partially due to metal-to-ligand charge transfer $\left(\mathrm{d}_{\mathrm{M}}-\pi^{*}{ }_{\text {Phen }}\right)$, in the 700-930 nm two-photon spectral range. The complex bearing the more conjugated structure (Ru3PTFTF) displays the most evident bathochromic shift (from $750 \mathrm{~nm}$ in $\mathrm{Ru}(\mathrm{Phen})_{3}{ }^{2+}$ to $825 \mathrm{~nm}$ for Ru3PTFTF), the higher $\sigma_{2}$ values being obtained with the increasing number of fluorene units (350 GM at $750 \mathrm{~nm}$ for complex Ru3PFF for example, 13 times higher than for the parent complex $\mathrm{Ru}(\mathrm{Phen})_{3}{ }^{2+}$ at the same excitation wavelength).

In conclusion, the study of the optical properties of this original family of $\mathrm{Ru}(\mathrm{II})$ complexes, has shown the possibility to finely tune the two-photon absorption properties in an interesting spectral range for potential applications (therapy and optical power limiting in the near infra-red). Modelisations and theoretical calculations are planned, in order to confirm the attribution of most of the discussed electronic transitions.

\section{Experimental Section}

The two-photon absorption spectra of the complexes were determined in the $700-930 \mathrm{~nm}$ range by investigating their two-photon excited luminescence (2PEL)

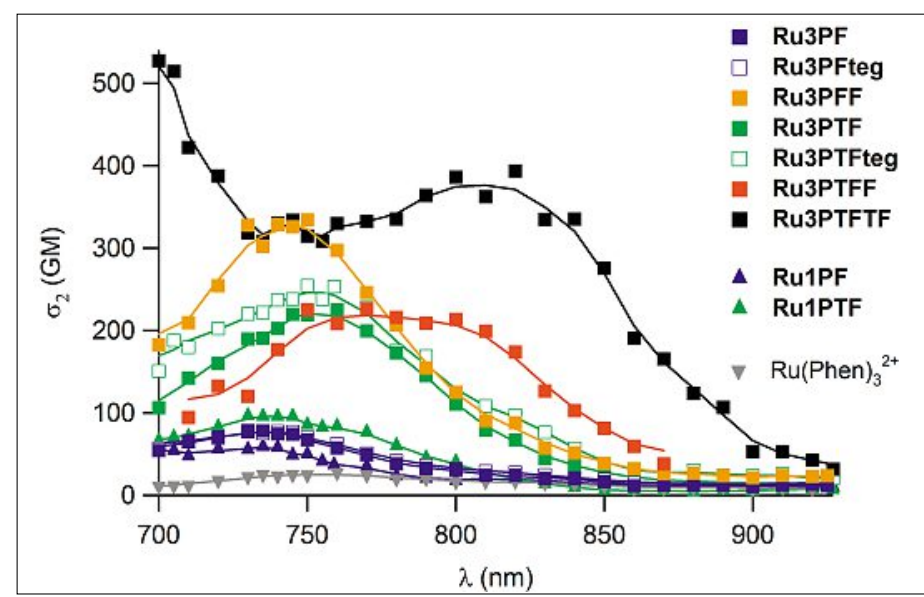

Fig. 3. Two-photon absorption spectra of Ru(II) complexes in the 700-930 nm spectral range.

Table 2. Two-photon absorption wavelength $\lambda_{2 \mathrm{PA}}{ }^{\text {max }}$ and related two-photon absorption cross-sections $\left(\sigma_{2 \mathrm{PA}}{ }^{\max }\right)$ given in acetonitrile for the studied $\mathrm{Ru}(\mathrm{II})$ complexes.

\begin{tabular}{|l|c|c|}
\hline Compound & $\begin{array}{c}\lambda_{2 \mathrm{~mA}}^{\max } \\
{[\mathrm{nm}]}\end{array}$ & $\begin{array}{c}\sigma_{2 \mathrm{~mA}} \\
{[\mathrm{GM}]}\end{array}$ \\
\hline Ru1PF & 735 & 60 \\
\hline Ru3PF & 735 & 80 \\
\hline Ru3PFteg & 735 & 90 \\
\hline Ru1PTF & 735 & 95 \\
\hline Ru3PTF & 760 & 225 \\
\hline Ru3PTFteg & 755 & 245 \\
\hline Ru3PFF & 740 & 330 \\
\hline Ru3PTFF & 770 & 225 \\
\hline Ru3PTFTF & 810,740 & 380,325 \\
\hline Ru(Phen) ${ }_{3}, 2$ PF $_{6}^{-}$ & 750 & 25 \\
\hline
\end{tabular}

in deoxygenated $10^{-4} \mathrm{M}$ acetonitrile or dichloromethane solutions. The measurements were performed using a Nd:YLFpumped Ti:sapphire oscillator generating $150 \mathrm{fs}$ pulses at a $76 \mathrm{MHz}$ rate. The excitation was focused into the cuvette through a microscope objective $(10 \times$, NA 0.25$)$. The luminescence was detected in epifluorescence mode via a dichroic mirror (Chroma 675dcxru) and a barrier filter (Chroma e650sp-2p) by a compact CCD spectrometer module BWTek BTC112E. Total luminescence intensities were obtained by integrating the corrected emission spectra measured by this spectrometer. 2PA crosssections $\left(\sigma_{2 \mathrm{PA}}\right)$ were determined from the two-photon excited luminescence crosssections $\left(\sigma_{2 \mathrm{PA}} \mathrm{F}\right)$ and the luminescence emission quantum yield (F). 2PEL crosssections of $10^{-4} \mathrm{M}$ solutions were measured relative to a $10^{-4} \mathrm{M}$ solution of fluorescein in $0.01 \mathrm{M}$ aqueous $\mathrm{NaOH}$ for 715-930 $\mathrm{nm}$, using the well-established method described by $\mathrm{Xu}$ and $\mathrm{Webb}^{[29]}$ and the appropriate solvent-related refractive index corrections. ${ }^{[30]}$ Data points between 700 and $715 \mathrm{~nm}$ were corrected. ${ }^{[31]}$ The quadratic dependence of the luminescence intensity on the excitation power was checked for each sample and all wavelengths, indicating that the measurements were carried out in intensity regimes where saturation or photo- degradation did not occur.

Synthesis and characterizations of complexes $\mathrm{Ru}(\mathrm{Phen})_{3}, 2 \mathrm{PF}_{6}{ }^{-},{ }^{[32]}$ $\mathrm{Ru}$ (Phen) $)_{2} \mathrm{Cl}_{2},{ }^{[33]} \quad \mathrm{RuCl}_{2}(\mathrm{DMSO})_{4},{ }^{\text {, } 34]}$ Ru3PF and Ru3PFF, [20e] Ru3PTFF, [26] Ru3PTFTF, [27] Ru3PFteg, ${ }^{[25 e]}$ (and related ligands PF, PFF, PTFF, PTFTF, and PFteg) have already been described elsewhere. Analogous procedures were used for Ru1PF, Ru1PTF, Ru3PTF, and Ru3PTFteg. ${ }^{1} \mathrm{H}$ and ${ }^{13} \mathrm{C}$ NMR spectra were recorded on a Bruker DPX 200 spectrometer (at 200.13 MHz for ${ }^{1} \mathrm{H}$ and 50.32 $\mathrm{MHz}$ for ${ }^{13} \mathrm{C}$ ) and also on a Varian Unity Plus at $499.84 \mathrm{MHz}$ for ${ }^{1} \mathrm{H}$. Elemental analyses were carried out by the 'Service Central d'Analyse', CNRS. UV/Vis spectra were recorded in the $200-800 \mathrm{~nm}$ range on a UV/Vis Jasco V-550; $\lambda_{\text {max }}$ are given in $\mathrm{nm}$ and molar absorption coefficients $\varepsilon$ in L. $\mathrm{mol}^{-1} \mathrm{~cm}^{-1}$.

Ru1PF: $156 \mathrm{mg}(0.29 \mathrm{mmol})$ of $\mathrm{Ru}$ (phen) ${ }_{2} \mathrm{Cl}_{2}$ were added under argon, to a solution of $150 \mathrm{mg}(0.29 \mathrm{mmol}, 1$ equiv.) of ligand PF dissolved in $10 \mathrm{~mL}$ anhydrous DMF. The reaction mixture was then refluxed for a night. Saturated aqueous solution of $\mathrm{NH}_{4} \mathrm{PF}_{6}$ was added to the resulting solution at room temperature. The precipitate was collected by filtration, washed three times with $\mathrm{H}_{2} \mathrm{O}$ and twice with pentane to give $330 \mathrm{mg}$ of a red-brownish solid with $90 \%$ yield. m.p.: not found $\left(20-450{ }^{\circ} \mathrm{C}\right)$. A fraction was recrystallized in EtOH for analysis. ${ }^{1} \mathrm{H}$ NMR (499.84 MHz, CD 3 CN) $\delta$ (ppm) 8.63-8.47 $(\mathrm{m}, 5 \mathrm{H}), 8.27-8.25(\mathrm{~m}, 4 \mathrm{H}), 8.11-7.80$ $(\mathrm{m}, 9 \mathrm{H}), 7.68-7.40(\mathrm{~m}, 12 \mathrm{H}), 2.09-2.07$ $(\mathrm{m}, 4 \mathrm{H}), 1.12-1.03(\mathrm{~m}, 12 \mathrm{H}), 0.77-0.62$ $(\mathrm{m}, 10 \mathrm{H})$. IR $\left(\mathrm{KBr}, \mathrm{cm}^{-1}\right): 3448\left(\mathrm{H}_{2} \mathrm{O}\right)$, $2927\left(\mathrm{VC}-\mathrm{H}_{\mathrm{akyl}}\right), 2854\left(\delta \mathrm{C}-\mathrm{H}_{\text {alkv1 }}\right), 1623$, $1427\left(\mathrm{vC}=\mathrm{C}_{\mathrm{aro}}\right), 843,721\left(\mathrm{vC}-\mathrm{H}_{\mathrm{aro}}\right), 557$; Anal. calcd. for $\mathrm{C}_{61} \mathrm{H}_{56} \mathrm{~F}_{12} \mathrm{~N}_{6} \mathrm{P}_{2} \mathrm{Ru}, 2 \mathrm{EtOH}$, 1.5 H $\mathrm{H}_{2} \mathrm{O}$ C, 56.44; H, 5.17; N, 6.07; Ru, 7.3. Found: C, 56.70; H, 4.64; N, 5.96; Ru, $6.72 \%$.

Ru1PTF: $150 \mathrm{mg}(0.28 \mathrm{mmol})$ of $\mathrm{Ru}$ (phen) $)_{2} \mathrm{Cl}_{2}$ were added under argon, to 
a solution of $150 \mathrm{mg}(0,29 \mathrm{mmol}, 1$ equiv. $)$ of ligand PTF dissolved in $10 \mathrm{~mL}$ anhydrous DMF. The reaction mixture was then refluxed for a night. Saturated aqueous solution of $\mathrm{NH}_{4} \mathrm{PF}_{6}$ was added to the resulting solution at room temperature. The precipitate was collected by filtration, washed three times with $\mathrm{H}_{2} \mathrm{O}$ and twice with pentane to give $268 \mathrm{mg}$ of a red-brownish solid with $74 \%$ yield. m.p.: not found $\left(20-450{ }^{\circ} \mathrm{C}\right) .{ }^{1} \mathrm{H}$ NMR (499.84 $\left.\mathrm{MHz}, \mathrm{CD}_{3} \mathrm{CN}\right) \delta(\mathrm{ppm}) 8.62-8.43(\mathrm{~m}, 5 \mathrm{H})$, $8.26-8.25^{3}(\mathrm{~m}, 3 \mathrm{H}), 8.17-8.00(\mathrm{~m}, 5 \mathrm{H})$, 7.89-7.60 (m, 10H), 2.11-2.06 (m, 4H), 1.10-1.02 (m, 12H), 0.77-0.73 (m, 6H), 0.57-0.54 (m, 4H). IR (KBr, cm $\left.{ }^{-1}\right): 3064$ $\left(\mathrm{H}_{2} \mathrm{O}\right), 2926\left(\mathrm{vC}-\mathrm{H}_{\text {alkyl }}\right), 2854\left(\mathrm{vC}-\mathrm{H}_{\text {alkyl }}\right)$, $1616,1427\left(\mathrm{vC}=\mathrm{C}_{\text {aro }}\right), 843,721$ ( $\delta \mathrm{C}$-Haro $)$, 557; Anal. calcd. for $\mathrm{C}_{63} \mathrm{H}_{56} \mathrm{~F}_{12} \mathrm{~N}_{6} \mathrm{P} 2 \mathrm{Ru}$ : C, 58.74; H, 4.38; N, 6.52; Ru, 7.85. Found: C, 58.83; H, 4.40; N, 6.56; Ru, 7.14\%.

Ru3PTFteg: $49 \mathrm{mg}$ of $\mathrm{RuCl}_{2}(\mathrm{DMSO})_{4}$ $(0,10 \mathrm{mmol})$ were added under argon, to a solution of $150 \mathrm{mg}(0,30 \mathrm{mmol}, 3$ equiv. $)$ of ligand PTFteg ( $0.30 \mathrm{mmol}, 3$ equiv.) dissolved in $8 \mathrm{~mL}$ ethanol. The reaction mixture was then refluxed for a night. Saturated aqueous solution of $\mathrm{NH}_{4} \mathrm{PF}_{6}$ was added to the resulting solution at room temperature. The precipitate was collected by filtration, washed three times with $\mathrm{H}_{2} \mathrm{O}$ and twice with diethyl ether to give $180 \mathrm{mg}$ of a red powder with $66 \%$ yield. m.p.: not found $\left(20-450{ }^{\circ} \mathrm{C}\right)$. A fraction was recrystallized in EtOH. ${ }^{1} \mathrm{H}$ NMR (499.84 MHz, $\left.\mathrm{CD}_{3} \mathrm{CN}\right) \delta(\mathrm{ppm}): 9.09-9.08(\mathrm{~m}, 1 \mathrm{H})$, 8.60-8.59 (m, 1H), 8.52 (s, 1H), 8.15-8.05 (m, 2H), 7.90-7.77 (m, 6 H), 7.49-7.41 (m, $3 \mathrm{H}), 3.47-3.14(\mathrm{~m}, 34 \mathrm{H}), 2.10-1.95$ (m, $4 \mathrm{H}), 0.83-0.81(\mathrm{~m}, 4 \mathrm{H})$; Anal. calcd. for $\mathrm{C}_{141} \mathrm{H}_{168} \mathrm{~F}_{12} \mathrm{~N}_{6} \mathrm{O}_{24} \mathrm{P}_{2} \mathrm{Ru}, 3 \mathrm{H}_{2} \mathrm{O}: \mathrm{C}, 61.01 ; \mathrm{H}$, 6.32; N, 3.03; Ru, 3.64. Found: C, 60.71; H, 6.34; N, 2.99; Ru, 3.64\%.

Received: June 24, 2015

[1] a) B. A. Reindhardt, Photonics Sci. News 1999 21; b) S. R. Marder, Chem. Comm. 2006, 131; c) M. Pawlicki, H. A. Collins, R. G. Denning, H. L. Anderson, Angew. Chem. Int. Ed. 2009 48, 3244; d) J. Zhou, Q. Liu, W. Feng, Y. Sun, F. Li, Chem. Rev. 2015, 115, 395.

[2] a) H. J. D. Bhawalkar, N. D. Kumar, C. F. Zhao, P. N. Prasad, J. Clin. Med. Surg. 1997, 15, 201; b) J. Liu, Y. W. Zhao, J. Q. Zhao, A. D. Xia, L. J. Jiang, S. Wu, L. Ma, Y. Q. Dong, Y. H. Gu, J. Photochem. Photobiol. B 2002, 68, 156; c) K. Ogawa, H. Hasegawa, Y. Inaba, Y. Kobuke, H. Inouye, Y. Kanemitsu, E. Kohno, T. Hirano, S. I. Ogura, I. Okura, J. Med. Chem. 2006, 49, 2276 ; d) B. C. Wilson, M. S. Patterson, Phys. Med. Biol. 2008, 53, 61; e) K. Ogawa, Y. Kobuke, BioMed Res. Int. 2013, article ID 125658, p. 11.

[3] S. R. Weksler, A. Mikhailovsky, D. Korystov, P. C. Ford, J. Am. Chem. Soc. 2006, 128, 3831.

[4] a) W. Denk, J.H. Strickler, W.W. Webb, Science 1990, 248, 73; b) Y. Shen, D. Jakubczyk, F. Xu, J. Swiatkiewicz, P. N. Prasad, B. A. Reinhardt, Appl. Phys. Lett. 2000, 76, 1

[5] a) D. A. Parthenopoulos, P.M. Rentzepis, Science 1989, 245, 843; b) J. H. Strickler, W.W. Webb, Opt. Lett. 1991, 16, 1780; c) H.
E. Pudavar, M. P. Joshi, P. N. Prasad, B. A. Reinhardt, Appl. Phys. Lett. 1999, 74, 1338.

[6] a) B. H. Cumpston, S. P. Ananthavel, S. Barlow, D.-L. Dyer, J. E Ehrlich, L.L. Erskine, A. A Heikal, S. M. Kuebler, I.-Y.S. Lee, D. McCordMaughon, J. Qin, H. Röckel, M. Rumi, X.-L. Wu, S. R. Marder, J. W. Perry, Nature 1999 398, 51; b) S. Kawata, H.-B. Sun, T. Tanaka, K. Takada, Nature 2001, 412, 697; c) W. Zhou, S. M. Kuebler, K. L. Braun, T. Yu, J. K. Cammack, C. K. Ober, J. W. Perry, S. R. Marder, Science 2002, 296, 1106

[7] J. E. Ehrlich, X.-L. Wu, I.-Y. S. Lee, Z.-Y. Hu H. Röckel, S. R. Marder, J. W. Perry, Opt. Lett. 1997, 22, 1843.

[8] a) F. Paul, B. G. Ellis, M. I. Bruce, L. Toupet, T. Roisnel, K. Costuas, J.-F. Halet, C. Lapinte, Organometallics 2006, 25, 649; b) S. K. Hurst, N. T. Lucas, M. G. Humphrey, T. Isoshima, K. Wostyn, I. Asselberghs, K. Clays, A. Persoons, M. Samoc, Inorg. Chim. Acta 2003, 350, 62; c) Z.M. Xue, Y.P. Tian, D. Wang, M. H. Jiang, J. Chem. Soc. Dalton Trans. 2003, 1373; d) A M. McDonagh, M. G. Humphrey, M. Samoc, B. Luther-Davies, Organometallics 1999, 18 , 5195.

[9] M. Albota, D. Beljonne, J.-L. Brédas, J. E. Ehrlich, J.-Y. Fu, A. A. Heikal, S. E. Hess, T. Kogej, M. D. Levin, S. R. Marder, D. McCordMaughon, J. W. Perry, H. Röckel, M. Rumi, G. Subramaniam, W. W. Webb, X.-L. Wu, C. Xu, Science 1998, 281, 1653.

[10] a) B. J. Coe, Acc. Chem. Res. 2006, 39, 383; b) K. Sénéchal, O. Maury, H. Le Bozec, I. Ledoux, J. Zyss, J. Am. Chem. Soc. 2002, 124, 4560; c) O. Maury, H. Le Bozec, Acc. Chem. Res. 2005 , 38, 691 .

[11] a) J. V. Caspar, T. J. Meyer, J. Am. Chem. Soc. 1983, 105, 5583; b) A. Juris, V. Balzani, F. Barigelletti, S. Campagna, P. Belser, A. Von Zelewsky, Coord. Chem. Rev. 1988, 84, 85.

[12] a) J. W. Dobrucki, J. Photochem. Photobiol. B: Biology 2001, 65, 136; b) K. D. Belfield, M. V. Bondara, O. V. Przhonska, J. Fluorescence 2006, 16, 111; c) S. Yao, K. D. Belfield, Eur. J. Org. Chem. 2012, 3199.

[13] a) Y. Morel, A. Irimia, P. Najechalski, Y. Kervella, O. Stephan, P. L. Baldeck, C. Andraud, J. Chem. Phys. 2001, 114, 5391; b) M. G. Silly, L. Porrès, O. Mongin, P.-A. Chollet, M. BlanchardDesce, Chem. Phys. Lett. 2003, 379, 74.

[14] a) F. N. Castellano, H. Malak, I. Gryczynski, J. R. Lakowicz, Inorg. Chem. 1997, 36, 5548; b) S. K. Hurst, M. P. Cifuentes, J. P. L. Morrall, N. T. Lucas, I. R. Whittall, M. G. Humphrey, I. Asselberghs, A. Persoons, M. Samoc, B. Luther-Davies, A. C. Willis, Organometallics 2001, 20, 4664; c) B. J. Coe, M. Samoc, A. Samoc, L. Zhu, Y. Yi, Z. Shuai, J. Phys. Chem. 2007, 111, 472.

[15] J. R. Lakowicz, F. N. Castellano, I. Gryczynski, Z. Gryczynski, J. D. Dattelbaum, J. Photochem. Photobiol A. 1999, 122, 95.

[16] a) C. E. Powell, J. P. Morrall, S. A. Ward, M. P. Cifuentes, E. G. A. Notars, M. Samoc, M. G. Humphrey, J. Am. Chem. Soc. 2004, 126, 12234; b) J. L. Humphrey, D. Kuciauskas, $J$ Am. Chem. Soc. 2006, 128, 3902.

[17] a) F. Gao, H. Chao, L.-N. Ji, Chemistry \& Biodiversity 2008, 5, 1962.; b) M. R. Gill, J. A. Thomas, Chem. Soc. Rev. 2012, 41, 3179.

[18] a) P. P. Lainé, S. Campagna, F. Loiseau, Coord. Chem. Rev. 2008, 252, 2552; b) Q. Sun, S. Mosquera-Vazquez, Y. Suffren, J. Hankache, N. Amstutz, L. M. Lawson Daku, E. Vauthey, A. Hauser, Coord. Chem. Rev. 2015, 282, 87.

[19] a) B. Coe, J. A. Harris, B. S. Brunschwig, I. Asselberghs, K. Clays, J. Garin, J. Orduna, J. Am. Chem. Soc. 2005, 127, 13399; b) L. Boubekeur-Lecaque, B. J. Coe, J. A. Harris, M. Helliwell, I. Assellberghs, K. Clays, S. Foerrier, T. Verbiest, Inorg. Chem. 2011, 50, 12886; c) S.
Fantacci and F. De Angelis, Coord. Chem. Rev. 2011, 255, 2704

[20] a) S. K. Hurst, M. G. Humphrey, J. P Morrall, M. P. Cifuentes, M. Samoc, B. Luther-Davis, G. A. Heath, A. C. Willis, J. Organomet. Chem. 2003, 670, 56; b) B. J. Coe, M. Samoc, A. Samoc, L. Zhu, Y. Yi, Z. Shuai, J. Phys. Chem. A 2007, 111, 472; c) C. Feuvrie, O. Maury, H. Le Bozec, I. Ledoux, J. P. Morrall, G.T. Dalton, M. Samoc, M. G. Humphrey, J. Phys. Chem. A 2007, 111, 8980; d) M. Samoc, J. P. Morrall, G. T. Dalton, M. P. Cifuentes, M. G. Humphrey, Angew. Chem. Int. Ed. 2007, 46, 731; e) C. Girardot, G. Lemercier, J.-C. Mulatier, J. Chauvin, P. L. Baldeck, C. Andraud, Dalton Trans. 2007, 3421; f) G. Lemercier, A. Bonne, M. Four, L. M. Lawson-Daku, C. R. Chimie 2008, 11, 709 .

[21] J. D. Knoll, C. Turro, Coord. Chem. Rev. 2015, 282, 110.

[22] a) A. Reynal, E. Palomares, Eur. J. Inorg. Chem. 2011, 4509; b) Y. Numata, S. Zhang, X. Yang, L. Han, Chem. Lett. 2013, 42, 1328.

[23] a) M. G. Humphrey, B. Lockhart-Gillet, M. Samoc, B. W. Skelton, V.-A. Tolhurst, A. H. White, A. J. Wilson, B. F. Yates, J. Organomet. Chem. 2005, 690, 1487; b) C. E. Powell, M. P. Cifuentes, M. G. Humphrey, A.C. Willis, J. P. Morrall, M. Samoc, Polyhedron 2007, 26, 284; c) T. V. Duncan, P. R. Frail, I. R. Miloradovic, M. J. Therien, J. Phys. Chem. B 2010, 114, 14696

[24] a) P. Hartmann, W. Ziegler, Anal. Chem. 1996, 68,4512 ; b) B. Elias, A. Kirsch-De Mesmaeker, Coord. Chem. Rev. 2006, 250, 1627.

[25] a) L. Tan-Sien-Hee, L. Jacquet, A. KirschDe Mesmaeker, J. Photochem. Photobiol. A: Chem. 1994, 81, 169; b) A. A. Abdel-Shafi, P. D. Beer, R. J. Mortimer, F. Wilkinson, PhysChemChemPhys 2000, 2, 3137; c) A. A. Abdel-Shafi, P. D. Beer, R. J. Mortimer, F. Wilkinson, J. Phys. Chem. A 2000, 104, 192; d) F. Schmitt, P. Govndaswamy, G. Süss-Fink, W. H. Ang, P. J. Dyson, L. Juillerat-Jeanneret, B. Therrien, J. Med. Chem. 2008, 51, 1811; e) Y. Liu, R. Hammitt, D. A. Lutterman, L. E. Joyce, R. P. Thummel, C. Turro, Inorg. Chem. 2009, 48, 375; f) C. Boca, M. Four, A. Bonne, B. van Der Sanden, S. Astilean, P. L. Baldeck, G. Lemercier, Chem. Commun. 2009, 4590.

[26] C. Girardot, B. Cao, J.-C. Mulatier, P. L. Baldeck, J. Chauvin, D. Riehl, J. A. Delaire, C. Andraud, G. Lemercier, ChemPhysChem 2008, 9, 1531.

[27] M. Four, D. Riehl, O. Mongin, M. BlanchardDesce, L. Max Lawson-Daku, J. Moreau, J. Chauvin, J. A. Delaire, G. Lemercier, PhysChemChemPhys 2011, 13, 17304.

[28] a) R. Anémian, J.-C. Mulatier, C. Andraud, O. Stéphan, J. C. Vial, Chem. Comm. 2002, 1608; b) R. Fortrie, R. Anémian, O. Stéphan, J.-C. Mulatier, P. L. Baldeck, C. Andraud, H. Chermette, J. Phys. Chem. C 2007, 111, 2270.

[29] C. Xu, W. W. Webb, J. Opt. Soc. Am. B 1996, 13,481 .

[30] M. H. V. Werts, N. Nerambourg, D. Pelegry, Y. Le Grand, M. Blanchard-Desce, Photochem. Photobiol. Sci. 2005, 4, 531.

[31] C. Katan, S. Tretiak, M. H. V. Werts, A. J. Bain, R. J. Marsh, N. Leonczek, N. Nicolaou, E. Badaeva, O. Mongin, M. Blanchard-Desce, $J$. Phys. Chem. B 2007, 111, 9468.

[32] J. N. Braddock, T. J. Meyer, J. Am. Chem. Soc. 1973, 95, 3158.

[33] a) P. J. Giordano, C. R. Bock, M. S. Wrighton, J. Am. Chem. Soc. 1978, 100, 6960; b) J. W. Hackett, C. Turro, Inorg. Chem. 1998, 37, 2039.

[34] I. P. Evans, A. Spencer, G. Wilkinson, J. Chem. Soc. Dalton Trans. 1973, 204. 